Martin Engel

\title{
Common Patterns of Consensual Conflict Resolution
}

\section{Zusammenfassung}

Einvernehmliche Streitbeilegung gibt es seit Menschengedenken. In den letzten Jahren haben die Mediationsrichtlinie sowie zwei weitere Regulierungsvorschläge der Europäischen Union den Methoden alternativer Konfliktlösung neue Aufmerksamkeit beschert. Der Beitrag beleuchtet verschiedene Ordnungsmuster konsensualer Streitbeilegung, erörtert den gegenwärtigen Stand dieser Methoden in Europa und beschäftigt sich schließlich mit der Frage, welche Rolle der nationale Gesetzgeber bei der Förderung alternativer Streitbeilegung spielen sollte.

\section{Résumé}

Les modes alternatifs de résolution des conflits ont toujours été utilisés afin de résoudre des conflits entre deux parties. Dernièrement, de nouvelles propositions de lois introduites par l'Union européenne captivent l'attention de la jurisprudence et de la pratique juridique. Dans un premier temps, cet article présente divers modèles adaptés pour le règlement amiable des litiges juridiques. Ensuite, il élabore sur le statu quo des modes alternatifs de résolution des conflits en Europe, et enfin traite de la question sensible de la disposition du législateur à soutenir le développement des modèles extra-judiciaire avec des fonds publics.

\section{Introduction}

Most civil cases result in a settlement between the parties. Even disputes which are already pending in court are highly likely to be resolved by a compromise agreement regardless of the fact that court proceedings are essentially designed to provide a ruling against one of the parties. However, the truth is normally located somewhere between the parties' allegations so they are better off settling instead of yielding the control over the outcome of their case to some third person such as a judge.

The history of legal practice as well as modern negotiation theory have developed a number of different mechanisms for parties to a dispute to achieve a materially reasonable and at the same time cost-efficient settlement. This evolution is advantageous not only for those involved but also for the government, which can save the more administration costs the less cases are submitted to a court. Furthermore, states have a high stake in their people living peacefully together. For the legislative bodies, the question thus emerges how they can optimally support private engagement in consensus-oriented negotiations and to what extent governments might be well advised to provide some kind of structural framework for the settlement of private disputes. 
Within the last couple of years, European jurisprudence has seen a number of regulatory attempts to render the conditions of legal negotiations favorable for dispute settlement. The most recent proposal by the European Commission includes drafts of a directive on alternative dispute resolution and a regulation on online dispute resolution. As of today, it is still unclear whether these proposals will pass the Council of the EU and the European Parliament in the foreseeable future. However, another important piece of regulation has already passed the legislative bodies and is already implemented in nearly all of the EU member states: The mediation directive 2008/52/EG aims to make sure that mediation in cross-border civil and commercial cases is facilitated by certain statutes of limitation and confidentiality rules, and that mediation settlements are enforceable throughout all member states. ${ }^{1}$

For all that, the practice of alternative dispute resolution in Europe has remained remarkably scarce. Even though the rise of mediation and its siblings was predicted to bring the use of these methods on a par with traditional litigation, ${ }^{2}$ this forecast turned out to be over-optimistic. So far, alternative dispute resolution has remained a niche product, which might be known in some parts of the European societies but is still widely unused in legal practice.

This article initially sketches criteria for promising patterns of consensus-oriented negotiation models (II.). It then goes on to describe the spectrum of consensual conflict resolution, its scope, and its pitfalls (III.). This leads to the question to which extent governments should support the described models and private attempts to settle disputes $(I V$.). The final section concludes $(V$.).

\section{Quality Criteria for Negotiation Models}

The quality of conflict resolution is determined by the extent to which a dispute resolution model can satisfy the needs of the involved persons. Three criteria have emerged as being crucial for conducive negotiations: These are transaction cost savings, reduction of complexity, and enabling future business opportunities for the involved.

\section{Transaction Cost Savings}

When it comes to legal disputes one of the most popular myths is the belief that a conflict has to be a zero-sum game. In fact, game theory reveals that conflicts hold a considerable potential of value creation, which is dependent on the parties' reciprocal willingness to cooperate. ${ }^{3}$ At the same time, disputes naturally bear a huge downside potential for both parties: They can lose significant amounts of time and money when arguing for years over a subject that could have been settled a lot easier. When conflicts escalate, parties

1 Cf. Eidenmueller, SchiedsVZ 2005, 124 ff.; Nolan-Haley, Fordham Law Legal Studies Research Paper No. 1942391.

2 Cf. the still optimistic outlook from Nolan-Haley, 37 N. C. J. Int. Law Comm. Regul. 2012.

3 See e.g. Barash, The Survival Game: How Game Theory Explains the Biology of Cooperation and Competition, 2003, pp. $104 \mathrm{ff}$. 
tend to overinvest in a process that seems to promise an absolute victory but actually only eats up lawyers' fees and court costs. ${ }^{4}$ Transaction costs get out of control.

Transaction costs symbolize lose-lose situations in legal disputes. It is thus a legitimate aim for negotiation models to save as much transaction costs as possible. This includes saving time, opportunity costs, expenses for the legal department of a company and for the legal advice of external lawyers as well as the costs of the enforcement of verdicts and settlements. An advantageous negotiation pattern will thus foster early mutual cooperation: Whereas adversarial communication is regularly in danger of entering a spiral of mutual distrust, the classical prisoner's dilemma shows that negotiating parties will reach the optimal individual and collective result if, and only if, they dare to cooperate. ${ }^{5}$ Other than with cooperation, transaction cost can hardly be saved.

\section{Reduction of Complexity}

A second important criterion for the quality of dispute resolution models is their ability to reduce the complexity of an intricate conflict. The more a pattern is designed to include any unresolved matter between the parties into one negotiation with one comprehensive outcome the more usable it is for people who are stuck in the multitude of claims they have brought and motions they have filed so far.

As far as the applicable civil procedure law contains a section that enables parties with more than one pending action to merge the proceedings for the sake of economy in litigation it is possible to get one comprehensive decision on a number of legal issues. However, the simple fusion of several actions does not reduce the material complexity of that conflict. In order to do this it would be necessary to facilitate mutual accommodation in the light of opposing claims and their respective litigation risks. Conventional court proceedings comprise settlement negotiations that allow for this kind of mutual accommodation. However, even if their focus is on the interests of the parties the shadow of the law ${ }^{6}$ is quite dark inside the courtroom, meaning that it is not easy to escape the law as the predominant measure for the outcome of the debate. This can hinder truly cooperative negotiations and prevent the parties from reaching a really beneficial agreement.

\section{Potential Future Business}

A third aspect a legal dispute can benefit from is the possibility to increase the extent of future business of the parties - both individually and conjointly. The chances of future business are particularly dependent on the parties' willingness to cooperate and to pre-

4 Colman, Game Theory and Its Applications in the Social and Biological Sciences, 1999, pp. $197 \mathrm{f}$., calls this the Macbeth effect, referring to Shakespeare's Macbeth Act III Scene 4 with Macbeth saying: "I am in blood stepp'd in so far, that, should I wade no more, returning were as tedious as go o'er.".

5 Herman/Kennedy/Cary, Legal Counseling and Negotiating: A Practical Approach, 2001, pp. $134 \mathrm{ff}$.; Barash, footnote 3, pp. $67 \mathrm{ff}$.

6 Mnookin/Kornhauser, 88 Yale L. Rev. 1979, 950, 968. 
serve confidentiality as to whatever the other side discloses throughout the course of negotiations.

The reason for the invaluable importance of confidentiality can be seen in the fact that the parties' market reputation is almost irretrievable once affected by negative publicity on the occasion of a public lawsuit. Dispute resolution patterns which encourage parties to a higher self-command will therefore also help them to protect their reputation and thereby add value to their case. They also maintain a certain level of mutual respect that regularly allows them to continue their business connection in the future.

Sure enough, the confidentiality of negotiations out of court does have a very notable downside: Since there is no official third person involved who could supervise the lawfulness of the final settlement, private negotiations are the place to conclude illegal agreements, especially with regard to competition and antitrust laws. Amongst professionals in alternative dispute resolution, it is an open secret that many international highstake arbitrations and mediations are driven by the common attempt of both parties not only to confidentially settle the actual dispute but also to thereby lay the foundations for future anticompetitive agreements. This system works because the arbitrators and mediators have committed themselves to keep the negotiation matter secret, and they are remunerated well.

Potential future business thus functions as a quality driver for negotiation patterns from the view of the parties. However, seen from the government's perspective, this aspect is tainted with a grave reservation as regards the legality of the reached settlements.

\section{Methodical Spectrum of Consensual Dispute Resolution}

Whereas the preservation of business chances forms an aim that parties might be able to achieve either consensually or by involving some third neutral, saving transaction costs and reducing complexity are largely dependent on the emergence of cooperation between the parties. Thus, consensus-oriented negotiation models will as a rule yield better outcomes. Contemporary consensual dispute resolution comprehends a variety of distinctive methods, which are varyingly used in different realms of the law.

\section{Bilateral Negotiations}

The simplest pattern of consensual dispute resolution are plain bilateral negotiations between the parties and, as the case may be, also their lawyers. One is tempted to think that bilateral negotiations are not a model worth mentioning. However, especially as far as lawyers are involved these negotiations entail extensive behavioral incentives that a regulator wondering about appropriate rules of legal ethics will better take into consideration.

A lawyer's profession is to support his client by exploring the facts of the case, developing a legal analysis of her rights and obligations, and providing a recommendation 
about the best strategy to pursue her interests in the light of chances and risks of litigation. ${ }^{7}$ Ideally, a lawyer will exactly follow his client's interests because it is his duty to advise solely according to her goals and to refrain from any action that runs contrary to these. However, legal practice has proven to be different: Often enough, correspondence between lawyers does not deal with the application and interpretation of legal rules or with procedural risks of both parties. Instead, parts of the profession have developed a culture of writing down lengthy allegations without referring to the law at all. Interlawyer letters are frequently addressed to the opposing lawyer but in fact first and foremost written to be read by the own client. This is unfortunate, because by not explaining the risks of his case to the client, a lawyer can satisfy his overconfident client only in the short term. Sure enough, the client himself will pay the price in the long term.

In fact, lawyers would do better to regularly admit procedural risks even when facing the other lawyer because in most cases, the opponent will have figured out these risks himself long ago. Thus, by openly talking about litigation risks a lawyer can notably raise his credibility and at the same time open the door for an early settlement. Ironically, some lawyers concede that they would only aim for a settlement outside court if they perceive their case to be extremely weak. ${ }^{8}$ This seems unwise because every case has some weaknesses and an expectation value of less than $100 \%$ of the claim ${ }^{9}-$ so highquality legal advice should never blind out the possibility of settlement. By admitting a certain litigation risk a lawyer does not necessarily lose credibility when threatening with a lawsuit. Professional litigation funders make it possible even for risk-averse clients to sue their counterpart in cases with uncertain prospects of success.

Of course, in order to allow for an early inter-lawyer debate aiming at improving and converging the mutual legal evaluations it needs sophisticated lawyers on both sides. As long as this is not the case there is still hardly any risk in unilaterally admitting existing weaknesses because just by questioning his own legal opinion a lawyer will not cede any legal rights to the other side.

\section{Collaborative Law}

The realm of alternative dispute resolution has lately created a negotiation model that uses a self-paternalistic mechanism to foster cooperative communication on behalf of an efficient settlement. Stemming from the field of family law, so-called collaborative law has spread out from Minnesota all over the United States at the turn of the millennium and has now already reached some parts of Europe. ${ }^{10}$

7 See e.g. the ABA Model Rules of Professional Conduct, Rule 2.1: "In rendering advice, a lawyer may refer not only to law but to other considerations such as moral, economic, social and political factors, that may be relevant to the client's situation.".

8 This was one of the perceived disadvantages expressly mentioned by several lawyers in an online survey by the author amongst 65 Bavarian lawyers in early 2012.

9 Morawietz, 3 Bloomberg Corp. L. J. 2008, 659: "Only the lawyer who dares to predict a probability of $0 \%$ or of $100 \%$ could become liable for a wrong forecast, as whatever can go wrong, will sometimes go wrong.".

10 Strickland, 84 N. C. L. Rev. 2006, 979 ff.; Engel, Collaborative Law: Mediation ohne Mediator, 2010, pp. $68 \mathrm{f}$. 
Collaborative law is a pattern of structured communication between both parties and their lawyers (4-way settlement meetings). ${ }^{11}$ Both parties abide by an initial agreement to disclose relevant matters and to abstain from the threat of legal action. The specific idiom of collaborative law is its disqualification agreement: The parties limit their lawyers' briefs to the negotiations out of court: If any party takes legal action both lawyers are disqualified from further representing their clients so that the parties have to reach out for new lawyers. This leads to the so-called container effect: Being aware that the court option has become unattractive due to the artificially high costs associated with it parties have empirically shown a notably higher commitment to the cooperation process than in traditional negotiations. ${ }^{12}$

Of course, not every client will be game for entering a disqualification agreement that apparently needlessly increases the price for a potential court process. It is thus primarily parties with family conflicts involving third parties like children who need to be protected from the worst corollaries of the dispute who opt for collaborative law. At the same time, experience with this model shows that under specific circumstances patterns of consensual conflict resolution can emerge which meet the criteria of cost saving, complexity reduction, and maintaining some kind of a relationship between the parties in the future. However, in order to make them work it needs lawyers to recommend these models. A lawyer's recommendation for the one or other kind of legal procedure can hardly be substituted by any consideration or unilateral decision of the client.

\section{Mediation}

The third model of consensus-oriented negotiation involves a neutral third person, a mediator. Mediation is defined as negotiation supported by a neutral. However, the mediator himself does not negotiate or decide the content of the settlement, instead he just facilitates the communication between both parties and helps wherever a negotiation impasse occurs. Thus, mediation does not necessarily imply a final settlement - like arbitration or conciliation do - but leaves the control over the outcome to the parties, including the possibility of a negotiation breakdown without any result.

Mediation has been foretold a glorious future. After Frank Sander raised the public's awareness for the potential of consensual conflict resolution at the well-known Pound Conference in $1976^{13}$ the United States saw a real movement towards alternative dispute resolution in general and mediation in particular. This movement was predicted to catch on in Europe with a delay of about two decades. However, even though there are hardly any numbers on the factual use of mediation it is safe to say that there is no widespread use of mediation, neither in the United States nor in Europe. ${ }^{14}$ The insular use in major

11 Tesler, Collaborative Law: Achieving Effective Resolution in Divorce Without Litigation, 2008 , pp. $59 \mathrm{ff}$.

12 Macfarlane, The Emerging Phenomenon of Collaborative Family Law (CFL): A Qualitative Study of CFL Cases, 2005, pp. 39 f.; Schwab, 4 Pepp. Disp. Resol. L. J. 2004, 351, 379 f.

13 Sander, F.R.D. 1976, 111, 130 f.; Sander/Crespo, 5 Univ. St. Thomas L. J. 2008, 665 ff.

14 Velikonja, 72 Alb. L. Rev. 2009, 257, $269 \mathrm{f}$. 
business disputes ${ }^{15}$ or in small claims courts remains an exception that proves the rule. Consequentially, the optimism has meanwhile given way to the question why the vast majority of clients still prefers to take legal action instead of aiming for an amicable settlement.

And again, the answer can be found right in the offices of our lawyers. There is one fundamental difference between conventional negotiation and collaborative law on the one hand and mediation on the other hand: When setting off conventional negotiations or a dialogue via collaborative law, lawyers themselves retain control over the process. In contrast, when recommending mediation, lawyers delegate the process management to someone else (i.e., the mediator), which apparently impairs their own account. This seems to lower the willingness of lawyers to recommend mediation as an appropriate dispute resolution method even if they have generally agreed that these methods can be beneficial for the client. This explains why collaborative law - albeit quite a young negotiation model - has caught on quickly in the United States whereas mediation is still caught between the stools.

\section{Government Support for Dispute Resolution}

Given that patterns of consensual dispute resolution help to save transaction cost, to reduce conflict complexity, and to preserve business or family relationships between the parties governments might want to support these models parallel to holding up its own judiciary. This raises the question to what extent governments should support certain models of consensual dispute resolution or private attempts to foster settlements.

\section{EU Regulation Proposals}

The recent proposals by the European Commission for a directive on alternative dispute resolution and a regulation on online dispute resolution aim at establishing a comprehensive system of alternative dispute resolution in Europe. At the EU level, the Commission intends to set up an internet-based conflict allocation system that allows traders and consumers to find an appropriate provider of alternative dispute resolution through an online tool. The said ADR providers would regularly act on the national level, maybe specialize in certain industries, and together form a complete network so that the EUwide online allocator can assign at least one competent provider to every dispute. ${ }^{16}$ But more than that: The EU member states would be responsible for the completeness of this network so that they would have to fill the network gaps themselves with appropriate, state-organized ADR providers. ${ }^{17}$

15 The JAMS corporation, presumably being the largest provider for business mediation worldwide, employs more than 270 full-time mediators; see http://www.jamsadr.com.

16 European Commission Proposals on an ADR Directive (2011/0373) and an ODR Regulation (2011/0374); however, these regulation proposals do not only relate to consensus-oriented means of alternative dispute resolution but also to other methods like conciliation.

17 Art. 5 No. 3 and Reason 13 of the proposed ADR Directive. 
The Commission justifies its proposals with a need for sound cross-border trade between the member states. Aside from aspects like doubts as to the applicable law, differing languages, and large distances, uncertainty regarding factual legal protection would be one of the main barriers to cross-border trade in the EU. ${ }^{18}$ Meanwhile, the question arises if it should really be the state as the provider of the judiciary who organizes out-of-court dispute resolution. The quality criteria of good conflict resolution as laid out above point to the contrary: Dispute resolution patterns organized by some public administration tend to become fully, if not overly, differentiated over time. With good cause, the addressees of regulation claim their equality rights and thereby cause the regulator to enact a detailed system of rules that in turn is inconsistent with the approach of a mechanism that saves transaction costs and reduces complexity. Against this background, consensual conflict resolution seems to be a genuine private matter that governments should not needlessly interfere with. ${ }^{19}$

\section{Government as Guarantor of a Framework for Settlements}

If government is not an appropriate provider of alternative dispute resolution mechanisms it might still be called upon to install an allocation framework that makes it easier for parties to a dispute to find out which dispute resolution pattern fits their needs best. Such a framework could for example entail an online allocation mechanism like the one proposed by the European Commission or consist of a conflict allocator inside court like the one Frank Sander anciently suggested as a so-called multi-door courthouse. ${ }^{20}$

To establish such a framework is ambitious especially if this aims to refer parties and their disputes through a public allocation system to private dispute resolution providers. Those providers will call for being treated equally. A solution might be to refer parties only to lists of potential providers and leave the choice to them. This would allow a market for private dispute resolution to emerge even if it brings about the risk of vast provider lists that give no hint concerning the individual quality of dispute resolution.

\section{Supervision of the Quality of Legal Advice}

Yet, as the crucial key to a sound choice of dispute resolution mechanisms rests in the hands of the lawyers, an effective supervision of the quality of legal advice seems more important than any other measure discussed above. Given that the entry to any dispute resolution method or framework normally has to be preceded by a corresponding recommendation from a lawyer the most urgent question should be how lawyers can be effectively incentivized to advise their clients according to their needs, i.e., in many

18 European Contract Law in Consumer Transactions, Eurobarometer 321, 2011, p. 19.

19 A certain exception are settlements in front of civil courts - these are admittedly generally preferable to a court judgment; however, due to high transaction costs they will rarely get ahead the quality of an out-of-court settlement.

20 Sander, 3 Barrister 1976, 18 ff., 40 ff.; Ray/Clare, 1 Ohio St. J. Disp. Resol. 1985, 7 ff.; Kessler/Finkelstein, 37 Cath. U. L. Rev. 1988, 577 ff.; Sander/Crespo, 5 Univ. St. Thomas L. J. 2008, 665, $669 \mathrm{ff}$. 
cases according to the quality criteria for dispute resolution mechanisms described above.

In this regard, the government would be well advised to optimize the frame conditions for everyday legal advice. How lawyers advise their clients is substantially dependent on the monetary incentives set out by the calculation mode of lawyers' fees. From an economic viewpoint, contingency fees align the interests of lawyers and clients because a lawyer will only invest in a claim if the expected value is worth the effort. Meanwhile, value-based compensation aggravates the principal-agent problem because lawyers will tend to bring their cases in front of a court regardless of their prospects of success. Especially under the English rule for legal expenses, this regularly turns out to be unfortunate for the client because he has to bear the full litigation costs of both parties in a case where he reasonably should have never brought an action.

Despite of that, contingency fees are still widely forbidden in a number of countries, although to a different extent. ${ }^{21}$ Changing these rules might advance the clients' welfare and the aim of a clever conflict allocation to efficient dispute resolution mechanisms more than the implementation of sophisticated support mechanisms for the expansion of consensual conflict resolution.

\section{Conclusion}

Throughout the past 40 years different patterns of consensual conflict resolution have emerged and been applied to different extents. From the view of the parties, these methods pay off the more they can save transaction cost, reduce complexity, and preserve relationships and business opportunities. These objectives can be pursued by any consensual negotiation, be it bilateral negotiations, collaborative law, or mediation. The door opener for these mechanisms is high quality in legal advice. In order to reach this goal governments should rather focus on effective, incentive-based lawyers' fee regulation than on establishing elaborate conflict allocation frameworks.

21 The most prominent example for a very tight restriction as to the permissibility of contingency fees is Germany. Here, contingency fees are permitted only where the client would otherwise refrain from pursuing her legal rights due to her financial circumstances, cf. $\S 49 \mathrm{~b}$ Federal Code for the Legal Profession (BRAO), § 7 a Lawyers' Compensation Act (RVG). See also Kleine-Cosack, NJW 2007, 1405, 1406. A synopsis of the admissibility of contingency fees in different countries is provided by Hodges/Vogenauer/Tulibacka (ed.), The Costs and Funding of Civil Litigation: A Comparative Perspective, 2011, pp. 132 f., Table 2. 